\title{
Trees and Shrubs of Zerafshan State National Reserve, Uzbekistan
}

\author{
Muqaddas Kholbutayeva1, Hislat Haydarov², Flora Kabulova², Husniobod Akhmedova² \\ ${ }^{1}$ Jizzakh State Pedagogical Institute, Jizzax, Uzbekistan \\ ${ }^{2}$ Samarkand State University, Samarkand, Uzbekistan \\ Email: haydarov@rambler.ru
}

How to cite this paper: Kholbutayeva, M. Haydarov, H., Kabulova, F. and Akhmedova, H. (2020) Trees and Shrubs of Zerafshan State National Reserve, Uzbekistan. American Journal of Plant Sciences, 11, 1698-1705.

https://doi.org/10.4236/ajps.2020.1111121

Received: August 21, 2020

Accepted: November 14, 2020

Published: November 17, 2020

Copyright (c) 2020 by author(s) and Scientific Research Publishing Inc. This work is licensed under the Creative Commons Attribution International License (CC BY 4.0).

http://creativecommons.org/licenses/by/4.0/

\begin{abstract}
The riparian (tugai) forest ecosystems of Central Asia are a biodiversity hotspot with unique many trees and shrubs. Intense human pressure and global warming have caused habitat destruction in Zerafshan State National park and it's 23.5 ha. There grow more than 300 higher plants. We analysed the wild flora and the remains of the species diversity that previously existed on the site of the forestry enterprise, the modern biodiversity of trees and shrubs in the described territory are represented by 52 species from among representatives of 21 plant families. These monitoring and results indicated that some tree species might in the near future become extinct in the wild. We therefore recommend that the local people be encouraged to stop using these trees.
\end{abstract}

\section{Keywords}

Riparian Forest, Tugai Ecosystem, Monitoring, Human Pressure, Trees

\section{Introduction}

Uncontrolled use of plant resources for human well-being drives the loss of plant biodiversity worldwide [1] [2]. The study of plant biodiversity, development of ways of their integrated conservation and restoration continues to be an urgent problem. Such work is also carried out on the territory of the riparian forest of Uzbekistan, where a relatively large number of various plants grow [3] [4] [5] [6].

More than 300 species of vascular plants grow on the territory of the reserve. Among this biodiversity, a special place belongs to the basis of the riparian forest-woody and shrub plants.

For a long time, different species of Populus, Salix, Elaegnus, Tamarix, Pyrus, 
Rubus, Prunus, Ulmus, Juglans, Quercus, Halimodendron, Rosa, Cerasus and etc. have grown on the territory of the reserve. One of the valuable plants of the reserve is the population of Hippophae rhamnoides L. which of the largest area in Uzbekistan.

Before the establishment of the reserve in 1975, this territory belonged to the Samarkand forestry organization, where the species of Acacia, Gleditschia, Acer, Fraximus, Ulmus, Juglans, etc., which have planted. One of the great interests is the Malus Niedzweckiana Dieck. and the Red Book species Rhus coriaria L. that has recently appeared in the reserve.

The Elaegnus angustifolia L., Berberis integerrima Rgl., Atraphaxis seravschanica Pavl Halimodendron halodendron Vass. etc. were well tolerated under the arid conditions.

\section{Material and Methods}

\section{Study Site}

Riparian forest of Zerafshan State Reserve is located in the Samarkand region and covering an area of 23.5 ha (Figure 1). The Zarafshan State Nature Reserve is situated in the south-eastern part of Samarkand region. It extends from the Chapan-Ata mountain upstream along the right bank of the Zarafshan river. The nature reserve consists of two separate parts, the distance between them being $300 \mathrm{~m}$. The width of each part is $100-140 \mathrm{~m}$ and the average length is $47 \mathrm{~km}$.

The climate of this region is typical for continental subtropics and is distinguished by large amplitudes. The amplitude is very high both during the year and the day.

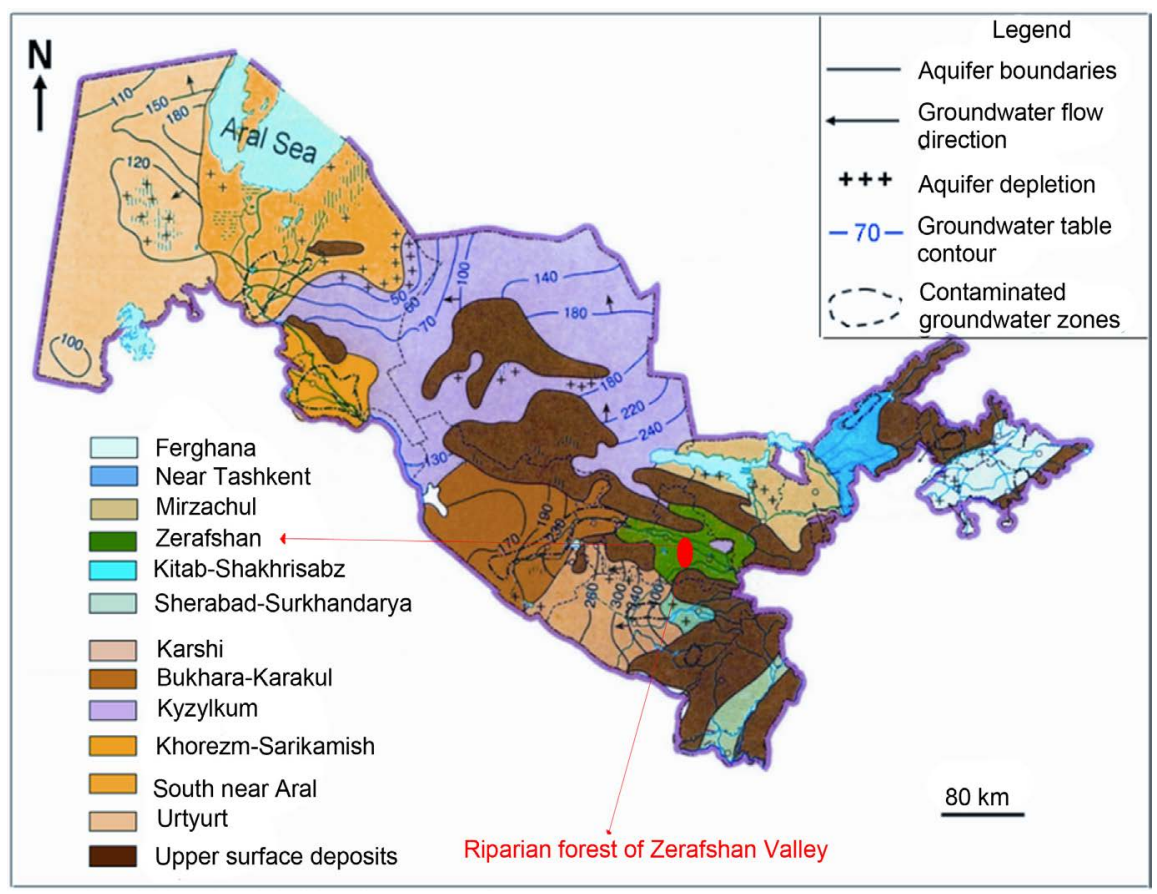

Figure 1. Map of the Zarafshan state reserve. 
The coldest month is January (-27), and the hottest is July (+41). In summer there is a lack of rain and the greatest aridity (Figure 2).

Precipitation in the area of the Zarafshan State Reserve is quite a small amount: from 100 to $400 \mathrm{~mm}$. and falls on the autumn-winter period. Precipitation falls in the form of rain and snow-from early December to the first ten days of March (Figure 3).

The number of days with snow cover does not exceed 30 days. The territory of the Zerafshan River basin is notable for a long duration of the sunshine, which is 2877 hours per year. The number of clear days is 150 - 160 days (Figure 4).

Samarkand. Mainly these focal species have used as wood and medicinal by local people.

Elaegnus angustifolia has got a firewood and it uses by local people. E. angustifolia and Hippophae rhamnoides are medicinal plants and people collect fruits of these focal species. And other species below are use as firewood by local people (Figure 5).

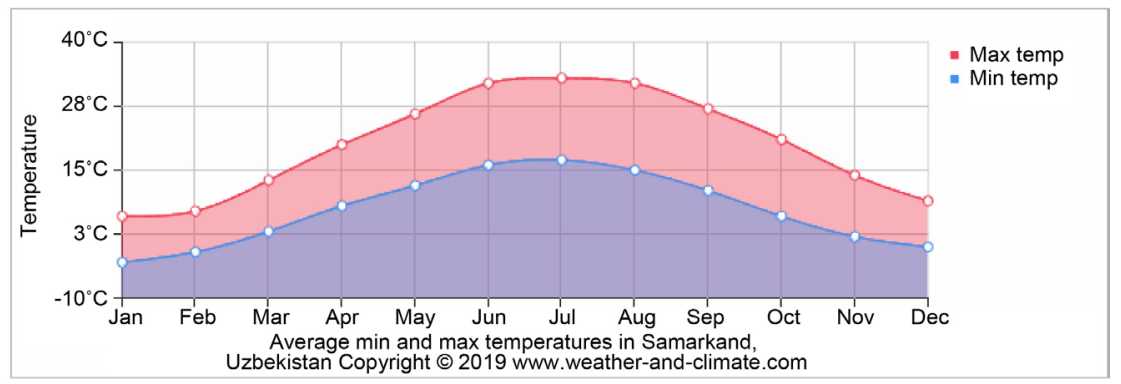

Figure 2. The mean minimum and maximum temperatures over the year, Samarkand.

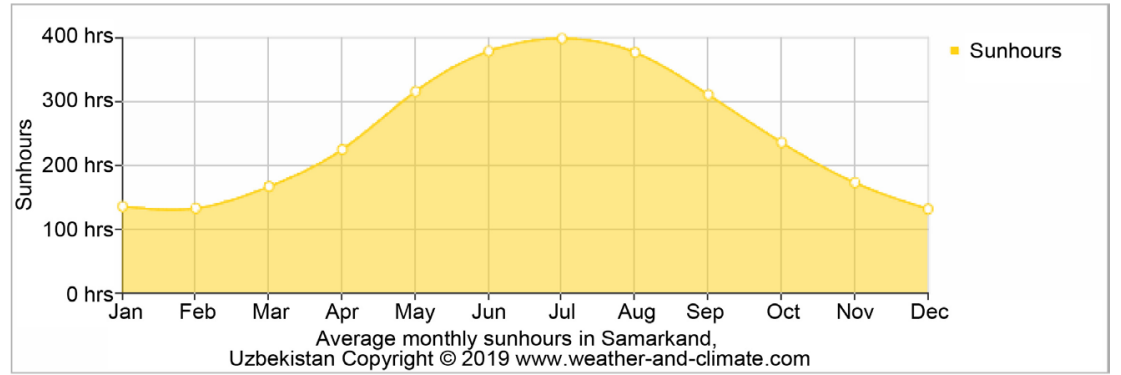

Figure 3. The monthly total of sun hours over the year in Samarkand.

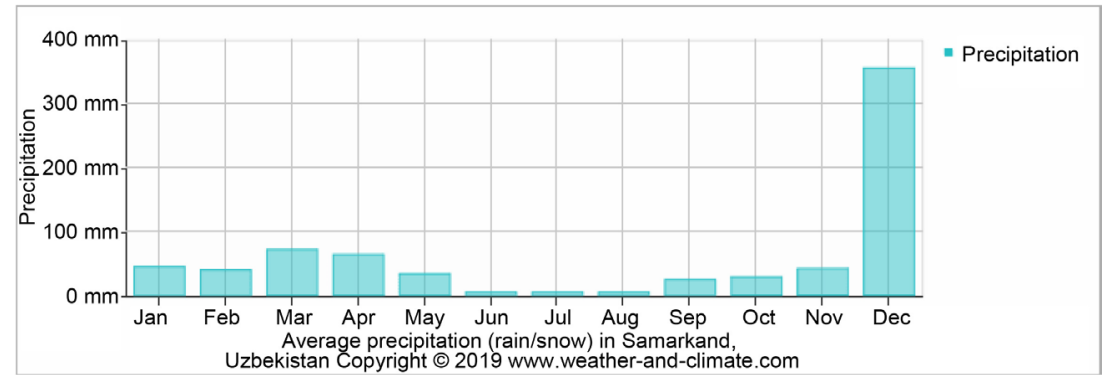

Figure 4. The mean monthly precipitation over the year, including rain, snow, hail etc. in Samarkand. Mainly these focal species have used as wood and medicinal by local people. 


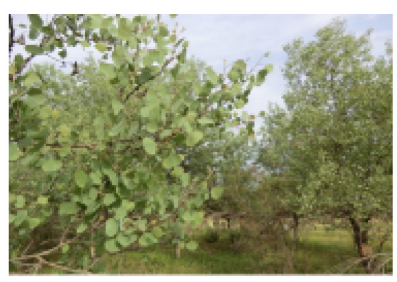

Populus pruinosa Schrenk.

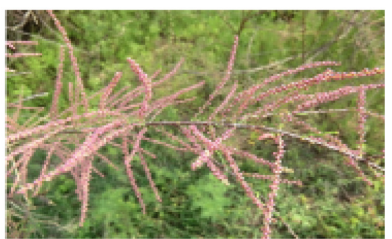

General view of Tamarix taxa Willd

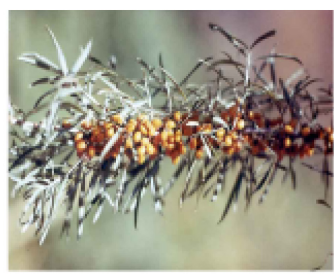

Hippophae rhamnoides $\mathrm{L}$.

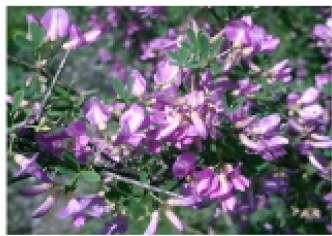

Halimodendron halodendron Vass.

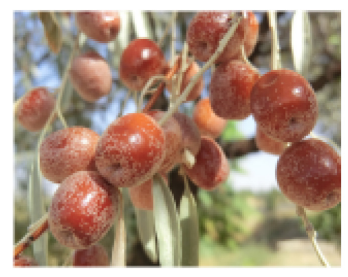

Elaegnas angustifolia L.

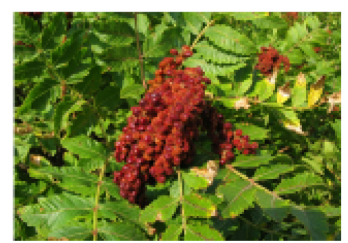

General view of Rhus coriaria L.

Figure 5. General view of focal species of Zarafshan state reserve.

Comparative botanical and geographical methods were mainly used in the study of taxonomic taxonomy of collected plants. The analysis of taxonomic units also used the flora of Uzbekistan. The life form of plants was described according to the 9th volume of Plant Identifier of Central Asia [7] into trees, shrubs, semi-shrubs, dwarf-shrubs, or herbs (perennial, biennial and annual). Plant taxonomy was according to Cherepanov 1995 [8].

Geobotanical research methods according to Rabotnov and Shennikov. Described on the basis of Uranov's manuals [9] [10] [11] and developed by Braun Blanquet 1965 [12].

\section{Results and Discussion}

The forests in the study region are mostly calm of Populus euphratica, Tamarix halostachys caspica, and Haloxylon ammodendron, and also some herbs such as Phragmites australis and Halimodendron halodendron. P. euphratica, is the keystone species of the riparian forests which are also reflected to as Tugai forests [13].

Tugai forests are the riparian forests along the rivers in the continental desert regions of Central Asia, i.e. the Tarim River, Amu Darya and Syr Darya. They mostly compose of Populus euphratica, Populus pruinosa and Elaeagnus oxycarpa Schltdl. As an investigation of land opening industries, large areas of Tugai forests were destroyed after the 1950s. Due to the excessive use of water for irrigation, the remaining Tugai forests are under serious danger. Near natural Tugai forests still exist along the Tarim middle reaches of the Tarim Huyanglin Nature Reserve, Xinjiang, NW China [14].

The Pesquería River (north-eastern Mexico) has long been exposed to significant anthropogenic pressures. For this reason, it has been identified by the Mexican National Commission for the Knowledge and Usage of Biodiversity as a priority resource to be priced and restored [15].

The riparian forests in the Tarim Basin (NW China) are mostly composed of 

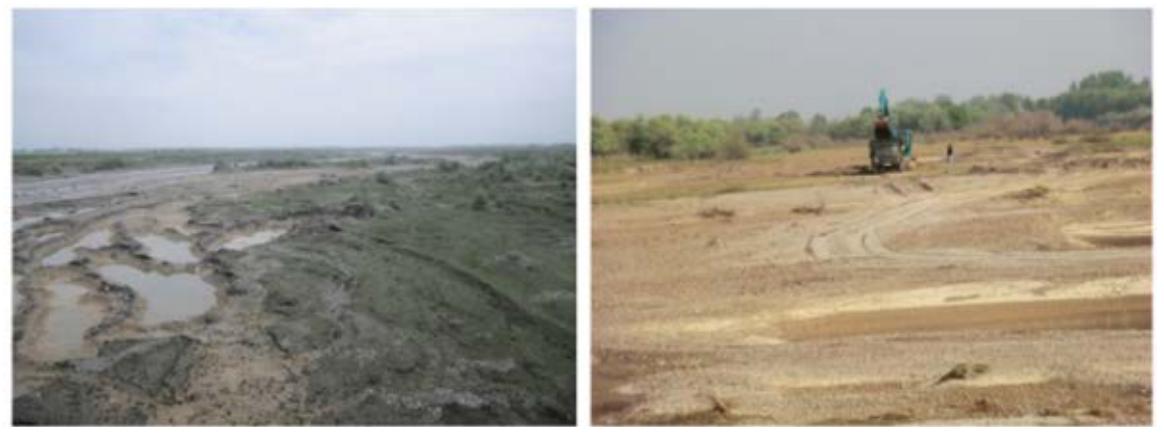

Figure 6. Degradation some part of Zerafshan state nature reserve.

Table 1. List of the trees and shrubs of the Zerafshan state nature reserve.

\begin{tabular}{|c|c|c|c|}
\hline № & Species & Life form & Braun-Blanquet, \% \\
\hline 1 & Pinus sativus $\mathrm{L}$. & Tree & $+=($ below one percentage $)$ \\
\hline 2 & Juniperus turkestanica Kom. & Tree & + \\
\hline 3 & Juniperus zeravschanica Kom. & Tree & + \\
\hline 4 & Salix babylonica L. & Tree & + \\
\hline 5 & Salix olgae Regel & Tree & 1 \\
\hline 6 & Salix turanica Nas. & Tree & + \\
\hline 7 & Salix Wilhelmsiana M. Bieb. & Tree & 2 \\
\hline 8 & Salix turanica Nas. & Tree & + \\
\hline 9 & Populus nigra $\mathrm{L}$. & Tree & + \\
\hline 10 & Populus Bachovenu Wierzb. & Tree & + \\
\hline 11 & Populus pruinosa Schrenk & Tree & 3 \\
\hline 12 & Populus diversifolia L. & Tree & 1 \\
\hline 13 & Juglans regia $\mathrm{L}$. & Tree & 1 \\
\hline 14 & Quercus robur $\mathrm{L}$. & Tree & 1 \\
\hline 15 & Morus alba L. & Tree & 1 \\
\hline 16 & Morus nigra L. & Tree & + \\
\hline 17 & Maclura aurantiaca Nitt. & Tree & 3 \\
\hline 18 & Ulmus parviflora Jacq. & Tree & 2 \\
\hline 19 & Platanus orientalis $\mathrm{L}$. & Tree & 1 \\
\hline 20 & Tamarix hispida Wild. & Tree & 3 \\
\hline 21 & Tamarix gracilis Bge. & Tree & + \\
\hline 22 & Tamarix arcentoides Bge. & Tree & + \\
\hline 23 & Tamarix laxa Willd. & Tree & 1 \\
\hline 24 & Elaegnus angustifolia L. & Tree & 5 \\
\hline 25 & $\begin{array}{l}\text { E.songarica (Bernh. ex Schltdl.) Fisch. ex } \\
\text { Trautv. }\end{array}$ & Tree & 2 \\
\hline 26 & Hippophae rhamnoides $\mathrm{L}$. & Tree & 5 \\
\hline 27 & Crataegus turkestanica A. Pojark. & Tree & 1 \\
\hline 28 & Crataegus songarica L. & Tree & + \\
\hline 29 & Prunus divaricata $L d b$. & Tree & 2 \\
\hline
\end{tabular}




\section{Continued}

\begin{tabular}{|c|c|c|c|}
\hline 30 & Cerasus mahaleb $(L)$ & Tree & 2 \\
\hline 31 & Cerasus vulgaris Mill.Gard. & Tree & 1 \\
\hline 32 & Cydonia oblonga Mill & Tree & 1 \\
\hline 33 & Persica vulgaris Mill. & Tree & + \\
\hline 34 & Malus domestica Borkh. & Tree & + \\
\hline 35 & Malus Niedzweckiana Dieck. & Tree & + \\
\hline 36 & Pyrus communis $\mathrm{L}$. & Tree & + \\
\hline 37 & Robinia pseudoacacia L. & Tree & + \\
\hline 38 & Gleditschia triacanthos $\mathrm{L}$. & Tree & 1 \\
\hline 39 & Halimodendron halodendron Vass. & Tree & 1 \\
\hline 40 & Ailanthus altissima Swingl. & Tree & 1 \\
\hline 41 & Rhus coriaria $\mathrm{L}$. & Tree & + \\
\hline 42 & Acer platanoides $\mathrm{L}$. & Tree & 1 \\
\hline 43 & Vitis vinifera $\mathrm{L}$. & Tree & + \\
\hline 44 & Hibiscus treonum $\mathrm{L}$. & Tree & + \\
\hline 45 & Fraximus excelsior $\mathrm{L}$. & Tree & + \\
\hline 46 & Berberis integerrima Rgl. & Shrub & 2 \\
\hline 47 & Ribes nigrum $\mathrm{L}$. & Shrub & + \\
\hline 48 & Atraphaxis seravschanica Pavl. & Shrub & 1 \\
\hline 49 & Rubus caesins $\mathrm{L}$. & Shrub & 3 \\
\hline 50 & Rosa canina L. & Shrub & 4 \\
\hline 51 & Rosa marakandica L. & Shrub & 2 \\
\hline 52 & Rosa Beggeriana L. & Shrub & 1 \\
\hline
\end{tabular}

poplar species (Populus euphratica, Populus pruinosa). In the hyper arid climate of this region, the trees are phreatophytes, which depend on access to groundwater. Essential ecosystem services (ESS) of these forests contain rationing, adjusting, and cultural services. Studies revealed that the wood of the forests could be sustainably used through a temperate harvesting intention [16].

This study investigated the anthropogenic pressure on the tugai forest. We observed Zerafshan tugai forest is under anthropogenic pressure and as well destroyed by erosion (Figure 6).

We analysed wood-shrubs of Zerafshan tugai forest, there were 45 trees and 7 shrubs. Mostly dominated by trees due to tolerance.

We usually identify trees and shrubs morphologic and anatomic characteristics and as well as modern approach is DNA analyse (Table 1).

\section{Conclusions and Recommendations}

The Zerafshan State Reserve is located near the settlements of four districts of the Samarkand region, does not have a fence, which creates problems for environmental protection measures. The main threat to the conservation and resto- 
ration of the reserve's vegetation is represented by deforestation, livestock grazing, collection of food and medicinal plants, and removal of gravel from the river bed. On the one hand, large trees are cut down, and on the other hand, young undergrowth is eaten by livestock. Thus, natural recovery is very slow. The removal of gravel leads to the fact that the level of groundwater goes down, and if you do not additionally irrigate the plants, they can die from lack of water. Therefore, in order to prevent these threats, first of all, it is necessary to conduct wider environmental education among the population and urgently develop ways to preserve and restore riparian vegetation in this area.

\section{Conflicts of Interest}

The authors declare no conflicts of interest regarding the publication of this paper.

\section{References}

[1] World Conservation Monitoring Centre (1992) Global Biodiversity: Status of the Earth's Living Resources. Chapman and Hall, London.

[2] IPCC (2001) The Scientific Basis. Contribution of Working Group I to the Third Assessment Report of the Intergovernmental Panel on Climate Change. Cambridge University Press, Cambridge, UK, 881.

[3] Aybergenov, B. and Kim, I. (2008) Proposals for Improving Reforestation in the Riparian Forests of Karakalpakstan. Materials of the Scientific-Practical Conference: Problems of Biodiversity Conservation in Protected Natural Areas of Uzbekistan. Nukus, 8-10.

[4] Kabulova, F.D. (2005) About Biodiversity of Plant Resources of Riparian Forest. Tashkent Bulletin “Tinbo". 25-30.

[5] Salimov, K.H.V. (2004) Some Changes in the Biogenesis of the Riparian of the Amu Darya River over the Past Quarter of a Century (on the Example of the Territory of the Kyzyl-Kum Reserve). Proceedings of the reserves of Uzbekistan. Status and Prospective Networks of Protected Areas in Central Asia, Tashkent, 324-333.

[6] Treshkin, S.E. (2001) Modern Problems of Preserving the Floristic Diversity of the Southern Aral Sea Region. In: Treshkin, S.E., Bakhiev, A.B., Mamutov, N. and Bakhieva P., Eds., Modern problems of preserving the floristic diversity of the Southern Aral Sea region, Bulletin of the KCO AS RUz, Nukus, 15-17.

[7] Abdulayeva (1987) Determiner of Plants Middle Asia; Critical Conspectus of Flora. Tashkent Fan, 9, 119-133.

[8] Czerepanov, S.K. (1995) Vascular Plants of Russia and Adjacent States (the Former USSR). Cambridge University Press, New York, 152 p.

[9] Rabotnov, T.A. (1950) Life Cycles of Perennial Grass Plants in Meadow Populations. Transactions of Institute of Botany of Academy of Sciences of USSR, Geobotany, Moscow, Leningrad, $176 \mathrm{p}$.

[10] Shennikov, A.P. (1964) Introduction to Geobotany-Leningrad. 224-348.

[11] Uranov, A.A. and Smirnova, O.V. (1969) Classification and Main Features of Development of Populations of Perennial Plants. Bulletin of Moscow Society of Naturalists, Department of Biology, 2, 119-134.

[12] Braun-Blanquet, J. (1965) Plant Sociology: The Study of Plant Communities. Hafn- 
er, London.

[13] Treshkin, S.Y. (2001) The Tugai Forests of Floodplain of the Amudarya River: Ecology, Dynamics and Their Conservation. In: Breckle, S.W., Veste, M. and Wucherer, W., Eds., Sustainable Land Use in Deserts, Springer, Berlin, 95-102. https://doi.org/10.1007/978-3-642-59560-8_9

[14] Thevs, N., Zerbe, S., Schnittler, M., Abdusalih, N. and Succow, M. (2008) Structure, Reproduction and Flood-Induced Dynamics of Riparian Tugai Forests at the Tarim River in Xinjiang, NW China. Forestry: An International Journal of Forest Research, 81, 45-57. https://doi.org/10.1093/forestry/cpm043

[15] Castro, D., Guerra, L.V. and Prat, C.N. (2018) The Role of Riparian Vegetation in the Evaluation of Ecosystem Health: The Case of Semiarid Conditions in Northern Mexico. River Research and Applications, 35, 48-59.

https://doi.org/10.1002/rra.3383

[16] Thomas, F.M. and Lang, P. (2020) Growth and Water Relations of Riparian Poplar Forests under Pressure in Central Asia's Tarim River Basin. River Research and Applications. https://doi.org/10.1002/rra.3605 